\title{
Future of Rangelands in the United States
}

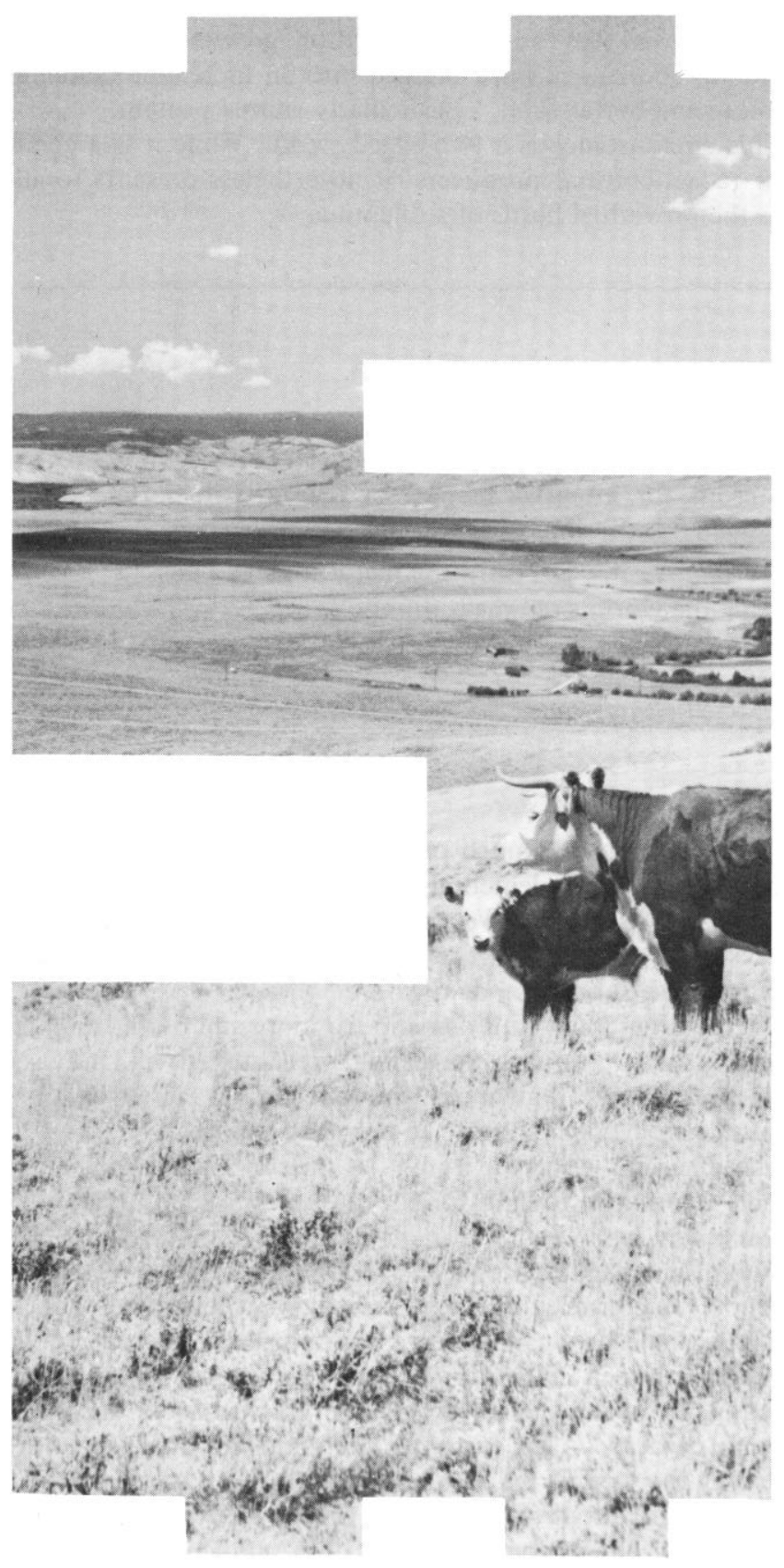

ROBERT W. LONG

Throughout our recent history the United States has had a tendency to group its national moods into segments of 10 years or so. Each decade is identified significantly.

For example, the twenties are remembered largely as a time of phenomenal growth, gaiety, and an initial baptism in world power politics.

Mention of the thirties brings memories of hardship, frustration, and a reassessment of domestic economic policy. This decade also spawned an array of farm programs that lingered far beyond their need.

The forties brought another world conflict with its aftershocks, and development of a policy of containment as an international strategy.

Then came the quieter fifties, which accelerated toward the end with our preparations for space exploration and a national reassessment of educational values.

The soaring, volatile sixties captured some of the emotional, environmental and economic moods of earlier times, yet the period suffered the spoilage of a futile mission in southeast Asia and its own shock waves of reaction.

Now we are in the middle of the seventies. We are more mature now about conflicts in the name of Democracy. We talk more urgently about the preservation of our environmental qualities. Some people have already become blase over the spectacular accomplishments of manned space travel.

And yet when this decade should be in a period of comfortable growth in all areas, we have run head-long into new domestic and international issues of considerable magnitude:

- Our world mechanical machine is running away from its propellant.

- We are rediscovering the full meaning of energy and inflation.

- We are taking a new look at the farmer and the rancher and learning anew the value of the marketplace and the meaning of a price mechanism as a governor for buyers and sellers.

- The nation is also concerned for the first time with basic supply problems - not just in energy, but in timber and even food.

These are not merely national issues. Some of them have become common denominators for our personal problems and are having a domino effect on our very life styles.

In short, our soaring systems have somehow sprung a leak and we are collectively struggling to keep our momentum.

The author is Assistant Secretary of Agriculture, Washington, D.C.

Paper was presented at the 27 th Annual Meeting, Society for Range Management, February 8, 1974, Tucson, Arizona. 
Yet despite our troubles, we have enjoyed some significant high notes. Detente is working. Also, two years ago the United States was running a serious deficit in our balance of trade. This year, however, we are in the black again and the primary reason is agriculture.

The 1973 agricultural trade surplus of $\$ 9.3$ billion wiped out a deficit of $\$ 7.6$ billion in nonagricultural trade. This left us with an overall 1973 trade surplus of $\$ 1.7$ billion. There's no doubt that the trade surplus in agriculture is stabilizing the dollar, strengthening our posture in international trade, and helping pay for much-needed oil and consumer goods that add so much to our level of affluence.

That surplus, incidentally, was built by the sale of $\$ 17.7$ billion of American agricultural products abroad during 1973, against food imports of $\$ 8.4$ billion.

1973 also brought the highest rate of employment in nearly 20 years. And it brought record levels of farm production and farm income. The latter, for instance, included net farm income of $\$ 26.1$ billion - nearly $78 \%$ more than the level of 5 years ago.

For all of us, the needs of the time dictate our priorities, and a major thrust of our efforts on the farm scene in the United States is found in our national agricultural policy. Five elements of that policy are particularly relevant:

(1) Through our Statistical Reporting System and other services, wc are establishing a reliable supply monitoring network to inform buyers and sellers of reserve levels of all basic crops.

(2) We are resisting the growth of trade barriers at home and abroad. Recent examples are the opening up of import quotas on wheat, beef, and dairy products. Record levels of our own farm products going into export markets give new emphasis to reciprocal trade agreements.

(3) We are maintaining a high level of agricultural research in state and federal systems. Of particular importance today is the need to maintain an efficient germ plasm bank to avoid a genetic vulnerability in seed varieties. Also of interest in your discussions at this meeting is that our Agricultural Research Service is conducting fertilization studies to increase the nutrient level in a wide spectrum of grasses. Other research at state stations and private research and development is delving into increased pest resistance of grasses and working to increase the protein control in many types of forage.

(4) We are more closely regulating trading in commodities which could be subject to abuse through excessive manipulation. The responsiblc agency is the Commodity Exchange Authority (CEA) which oversees activities in futures trading. It's timely that the CEA itself is undergoing an overhaul to increase its effectiveness.

(5) Finally, and most importantly, we are working to reduce the burden of government influence in the marketplace. A major part of this effort has been our turn-around from stifling control policies that have lingered in our country since the 1930's. With a few minor exceptions, the over-hang of Commodity Credit Corporation grain stocks is gone. We are getting out of the business of periodically depressing the market for these commodities. The price support payments that for a generation cost billions of tax dollars annually will this year be reduced to near zero. To repeat a phrase coined by Treasury Secretary George Schultz, "We are going to keep our cotton-pickin' hands out of the marketplace."

In the midst of all this activity, the reservoir of feed in our rangelands is demanding renewed attention. Here's why:
As one of America's most productive indutries, agriculture finds itself under heavy pressure because of a dramatic fact rapidly rising demand.

The prime element of this demand is the world's ballooning population. The global population reached the 1 billion mark about 1830 . In 1930 , only a century later, we reached the 2 billion mark. Thirty years later we added the third billion, and by 1975 this compounding rate of growth will take us to 4 billion.

Even the smallest child knows that somewhere, somehow, we must produce farm goods to feed all these consumers.

The second element of demand (even more striking than population statistics) is the fact that these 4 billion people are demanding a higher quality of life than any of their ancestors. This rising standard of living is not concentrated just in our hemisphere. It is occurring all around the globe.

In agricultural circles, one of the most celebrated facts of the decade is that all this population growth and relative economic abundance have merged into an incredible demand for more and better food - particularly animal protein.

This circumstance is a two-edged sword. While it is a great boon to agricultural producers, it nevertheless presents to all of us the proverbial horns of a dilemma.

\begin{abstract}
'We may need to decide between cultivation of crops for intensive feeding or investing in better yields from our grasslands to increase carrying capacity-it's currently the major factor in increasing the world's red meat supply."
\end{abstract}

On the one hand, much of our cultivated acreage is being used to produce supplemental feed for livestock, or we could say, "animal calories." We may need to explore alternative sources of nutrition for direct human consumption because we can't meet the short term demand.

On the other hand, this demand for more and better food is cutting into our available grassland. A recent study in land use conversion shows that more than 4 million acres of our grasslands are being converted to cropland this year.

The dilemma - and the irony - is this: In addition to being a viable alternative to cultivated feed, our rangeland represents the only way we know to corral the vast resource of the plains and mountain meadows for man's use. So far, it's the only way we know to convert the ranges into high-protein food. Yet a given rangeland area cannot serve both purposes. We may need to decide between cultivation of crops for intensive feeding or investing in better yields from our grasslands to increase carrying capacity - it's currently the major limiting factor in increasing the world's red meat supply.

There's no doubt that with proper development and management, our nation's ranges - both public and private have the potential to produce more pounds of meat than is currently the case. 
For the United States, this would have several interesting implications: Increased range utilization for livestock production can reduce the drainage on future national energy requirements for meat animals. Further, it can release more feed grains for overseas sale and, in effect, exchange for fuel or whatever is most critically in short supply. In this way, range production can contribute, however indirectly, to a more favorable economic balance for the nation's needs.

Here are some interesting notes on increased use of better managed rangelands as a source of livestock feed energy. Several independent studies have concluded that it takes about 22 gallons of gasoline per acre to produce corn. On the other hand, range livestock production has a much lower fossil fuel requirement - perhaps one twentieth - for the gross energy production that results.

Theoretically, for every acre of corn saved by tradeoff to range grazing (that is, about 87 bushels of corn), about 21 gallons of gasoline are also saved.

Consideration should also be given to the favorable characteristics of livestock grazing in the context of the environment. Livestock grazing of forest-range lands provides an opportunity to tap the energy of the sun without major alteration of natural ecosystems. It also yields few by-products alien to the ecosystems. It contributes significantly to a favorable nature

\footnotetext{
"This is our dilemma on land use. It is going to require that we ultimately have a national land use program to satisfy the multiple interests of our people."
}

must up-grade the carrying capacity of our ranges.

The Forest Service's Range Study, released last summer, estimates that by the year 2000 America's annual per capita consumption of beef will reach what may prove to be a conservative level of 135 pounds - $16 \%$ higher than it is today, even after the incredible $86 \%$ increase since 1950 .

The study also predicts that by 1980 the demand for range grazing to fulfill meat and wool needs will increase by $20 \%$ over the 1970 level, and by $50 \%$ at the end of the century.

Dovetail these factors with other projections - such as wood growth, water yield, wildlife habitat, scenery and recreational demands - and it's easy to see what a mamoth task we have ahead.

This is our dilemma on land use. It is going to require that we ultimately have a national land use program to satisfy the multiple interests of our people.

To maintain our claim for livestock use we must improve the varieties of grasses and forage crops, increase use of fertilizers and water, and integrate forage, range, and livestock management into more efficient systems. If we can do these things - coupled with a maximization of roughage sources like newspaper, wood pulp, peanut hulls, and corn stalks - we may make significant strides toward meeting the demand for red meat.

The U.S. Department of Agriculture is fundamentally a service agency designed to underwrite and provide support for these efforts. In that perspective: We administer grazing on 105 million acres of federal lands in the National Forest System. With this sizeable commitment it is understandable why we should be deeply involved in forest-range grazing and forest-range research. Additionally, with technical assistance through the Soil Conservation Service and educational programs from our Extension Service, we are aiding the private sector in range management and developing plant materials used in improving ranges. Through the Agricultural Research Service we are restudying the long-term implications of needed forage and range technology. And our Agricultural Stabilization and Conservation Service administers programs for rangeland resource protection and stabilization. Also, of course, other federal agencies - like the Bureau of Land Management, the Bureau of Indian Affairs, the National Park Service - also play significant roles in our nation's efforts to get maximum use from our rangelands.

The upshot of it all is that Mexico, Canada, and the United States comprise a mammoth complex of rangeland. And that very rangeland just might hold the answer to our supply problem in red meat. But like most problems, this one won't be solved by isolation of effort. We must respond in concert. We must communicate freely, exchanging views and sharing research findings.

The problem transcends national borders, and so must the solution. domestic demand for our grain products, and it's clear that we picture in terms of weed control, reduction of fire hazards, nd other factors.

our ranges, but we have a long way to go. One point of interest is the accelerated rangeland program that is in the opment stages at the U.S. Department of Agriculture. single use, including reforestation. In 1970, about 850 million production.

Based on our demand for more animal protein, during the next 10 years our nation will need nearly 1 million more beef 